永文・水窅源学会鿁

J. Japan Soc. Hydrol. \& Water Resour.

Vol. 9, No. 6 (1996) _p. 534-541

\title{
大台ケ原における樹雨観測と量的評価
}

\section{Observation of Fog Drip at Mt. Odaigahara and its Estimation}

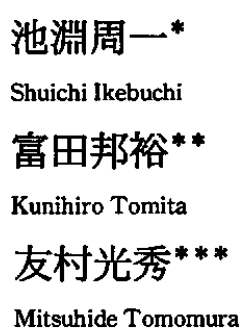

(京都大学防災研究所)

$D P R I$, Kyoto University

（建設省近畿地方建設局大滝ダム工事事務所）

Ministry of construction, Kinki Regional Construction Bureau, Otaki Dam Construction Office

(財)気象協会関西本部)

Japan Weather Association, Kansai Head Office

Observing the gross rainfall, throwfall, stemflow and soil moisture, we found out the existence of fog drip and estimated its amount. At the same time we explained the meteorological conditions for occurrence of fog drip. As a result, the amount of fog drip during the observational period was $94 \mathrm{~mm}$ and $90 \mathrm{~mm}$ in broad leaved and coniferous trees, respectively. Those are correspondent to about thirty percent of gross rainfall and are not ignorable value for water management.

Key words: Fog drip, Mt. Odaigahara, Gross rainfall, Throwfall, Stemflow

大台ヶ原頂上付近の森林地て, 林外雨, 林内雨, 樹幹流, 土境水分の観湘を実施し, 樹雨の存在とその量的評価をおこなうととも

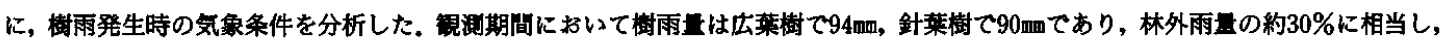
これは水管理上, 無視てきない量と考えられる。

キーワード：樹雨, 大台ケ原, 林外雨量, 林内雨豆, 橵幹流

\section{I .はじめに}

樹雨(きさめ)とは，㴎第が森林を流れていくとき に，雺粒が樹木の木の葉にとらえられ，風に吹き落 とされて大粒の雨となって降る現象を指す。こうし た樹雨は，通常の雨量計では観测されないが，林内 雨の一種であり, 通常の降雨時と同じように樹冠遮 断も生じている. また，直接的な测定は難しいが, 樹木による新の捕捉は濃霧を伴う降雨中にも発生す るであろう。ここでは, 流域の水文過程の把握とい
う視点から, 降雨のあるなしにかかわらず, 遮断蒸 発量を考慮したうえて，基本的には林内雨(樹幹流を 含む)と林外雨の差を樹雨として取り扱っている.

樹雨の観測例は少なく，南アフリカのテーブル山 やタスマニアのウェリングトン山などの例がある (鈴木, 1959). 我が国では, 日本一雨量の多い大台ヶ 原において大正12年真山俊雄が樹雨の存在を観剆し ていた(真山, 1923).

本研究は樹雨の存在を確認し，それを量的に把握 するため, 大台ヶ原頂上付近の森林地で林外雨, 林

\footnotetext{
*京大学防災研究所 $\mathbf{T} 611$ 宇治市五ヶ庄

Disaster Prevention Research Institute of Kyoto University, Gokasho,Uji, Kyoto 611

**建設省近蟣地方建設局大滝ダ厶工事重務所 †639-31 奈良県吉野郡吉野町河原屋128の1

Ministry of Construction, Kinki Regional Construcion Bureau, Otaki Dam Construction Office, 128-1 Kawaharaya, Yoshino town, Yoshino county, Nara Prefecture 639-31

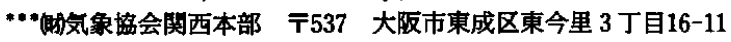

Japan Weather Association, Kansai Head Office, 3-16-11 Higashi Imazato, Higashi District, Osaka 537
} 
内雨，樹幹流，土壤水分の観測を実施するとともに， 風向・風速, 気温・湿度等の観測も同時におこない, 樹雨発生時の気象条件を分析した.こうした樹雨の 発生とその量的把㩧はこの地域の降雨・流出モデル の構成においても, また, 今後, 微物理過程を运入 した降雨シミュレーションモデルの下層境界条件の 構成にあっても重視すべき内容をもたらすものと思 われる。

\section{II . 大台ヶ原における樹雨観測}

\section{1. 樹雨観測の概要}

衣一 1 に示す観測機器を用いて，樹雨観測を実施 した. 图一1に，観測地点の位置図を示す。

樹雨の量を把握するための観測は，建設省大台雨 量観測所付近の森林に，環境庁の許可の下に設置し た機器を用いて実施した，図一2に，林内雨，樹幹 流，土壤水分の観測機器の配置を示す。なお，林外 雨は大台雨量観測所の観測值を用いた。観測は，隣 接する針葉樹と広葉樹の下で，それぞれ行った。

林内雨は, $19 \times 496 \mathrm{~cm}$ の長方形の受水口をもつ転倒 ます雨量計で計測した，受水口の面積から，1転倒 は0.0167m も測定する場所によって違いが大きいため，それぞ れ 3 本の転倒ますで計測し, それらの平均值を求め た。

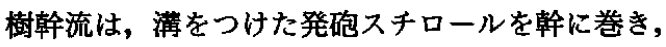
さらに, 幹との腙間を埋めて, 幹に伝ってくる樹幹 流を，転倒ます雨量計で計測した，樹冠の面積を， 針葉樹, 広葉樹とも, 直径 $10 \mathrm{~m} の 円$ 形と仮定した場合, 1 転倒は $0.0002 \mathrm{~mm}$ となる.なお，この樹冠面積に対 する林内雨の受水面積の割合は $3.6 \%$ てある.

土壤水分は，水を含んだ土壤の誘電率を電磁波を 用いて測定し，土壤水分量を求めるTDR (Timedomain Reflectometry)法(開発，1992)を用いたセン サー(GABEL社製Moisture Point)により，地中 0 $15 \mathrm{~cm}, 15 \sim 30 \mathrm{~cm}, 30 \sim 60 \mathrm{~cm}, 60 \sim 90 \mathrm{~cm}, 90 \sim 120 \mathrm{~cm}$ の 体積含水率を湘定した。

\section{表一 1 樹雨観測の概要と観測期閂}

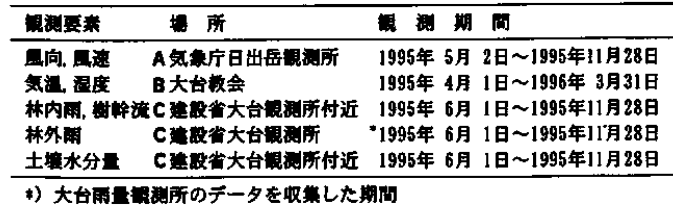

\section{2. 覾測データと測定状況}

林内雨は，3本の転倒ますで測られた雨量を平均 し，広葉樹と針葉樹とではデータの測定期間が異な るため，両者に共通する期間を採って統一し，集計 した．表一 2 がその結果であり，全体で，34の降雨 期間になった，表一 $2 て ゙ ，$ 広葉樹，針葉樹ともに林 内雨が林外雨よりも多く，明らかに樹雨の影響が あったと考えられる降雨は， $\triangle$ 印で示した。これを みると, 梅雨期 ( $6 \sim 7$ 月中旬), 秋期 ( $9 \sim 11$ 月) に多 く, 盛夏期(梅雨明け〜 8月)には比較的大きな降雨が あっても樹雨による増雨は少ないことがわかる。

\section{III. 樹雨䍃の算出}

图一 3 に，表一 2 の34降雨について，林外雨量と 林内雨量との関係を示す．全降雨の総雨量 (林外雨 量) は $731.0 \mathrm{~mm} て ゙$, 林内雨量は，広葉樹 $691.8 \mathrm{~mm}$, 針葉

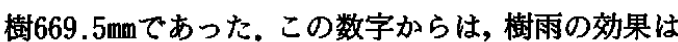
ないように思える。しかし，本来，林内雨量は图一 4 に示すように，林外雨量の約 $80 \%$ であり，残りの 約 $20 \%$ は樹冠遮断として蒸発してしまう(服部ら， 1989)。そこで，観測期間の樹雨量を，以下のように 算出した。

まず，表一 2 における林内雨が林外雨よりも少な い24降雨 ( $\Delta$ 印のついてない降雨)において，林外雨の 合計は $445.0 \mathrm{~mm}$ ，広葉樹林内雨量の合計は $363.7 \mathrm{~mm}$, 針葉樹林内雨量の合計は $353.1 \mathrm{~mm}$ である.林内雨量の 林外雨量に対する比率 $\mathrm{A}$ は，広葉樹が81.7\%，針葉 樹が79.3\%であり，両者とも約80\%であった。これ は，既往の研究結果(服部ら，1989）と一致する。たた し，これらの中には，林外雨量を超過するまでには 至らせないが，林内雨量に樹雨が含まれている可能 性のある降雨が存在する.このため, 本来の比率は, この值よりもやや低くなると考えられる。

次に, 林内雨量が林外雨量を超過し, 明らかに樹 雨が生じたと考えられる10降雨(表一 2 の 雨)においては, 林外雨の合計は $286.0 \mathrm{~mm}$, 広葉樹林内 雨量の合計は $328.1 \mathrm{~mm}$, 針葉樹林内雨量の合計は $316.5 \mathrm{~mm}$ あ゙る.これらの降雨について, 樹雨がない 場合の林内雨量を,

樹雨がない場合の林内雨量

$=$ 林外雨量 $\times$ 比率 $\mathrm{A}$

で推定しここれを観測された林内雨量から差し引い たものを樹雨量とした.

樹雨量 $=$ 林内雨量一林外雨量 $\times$ 比率 $\mathrm{A}$ 


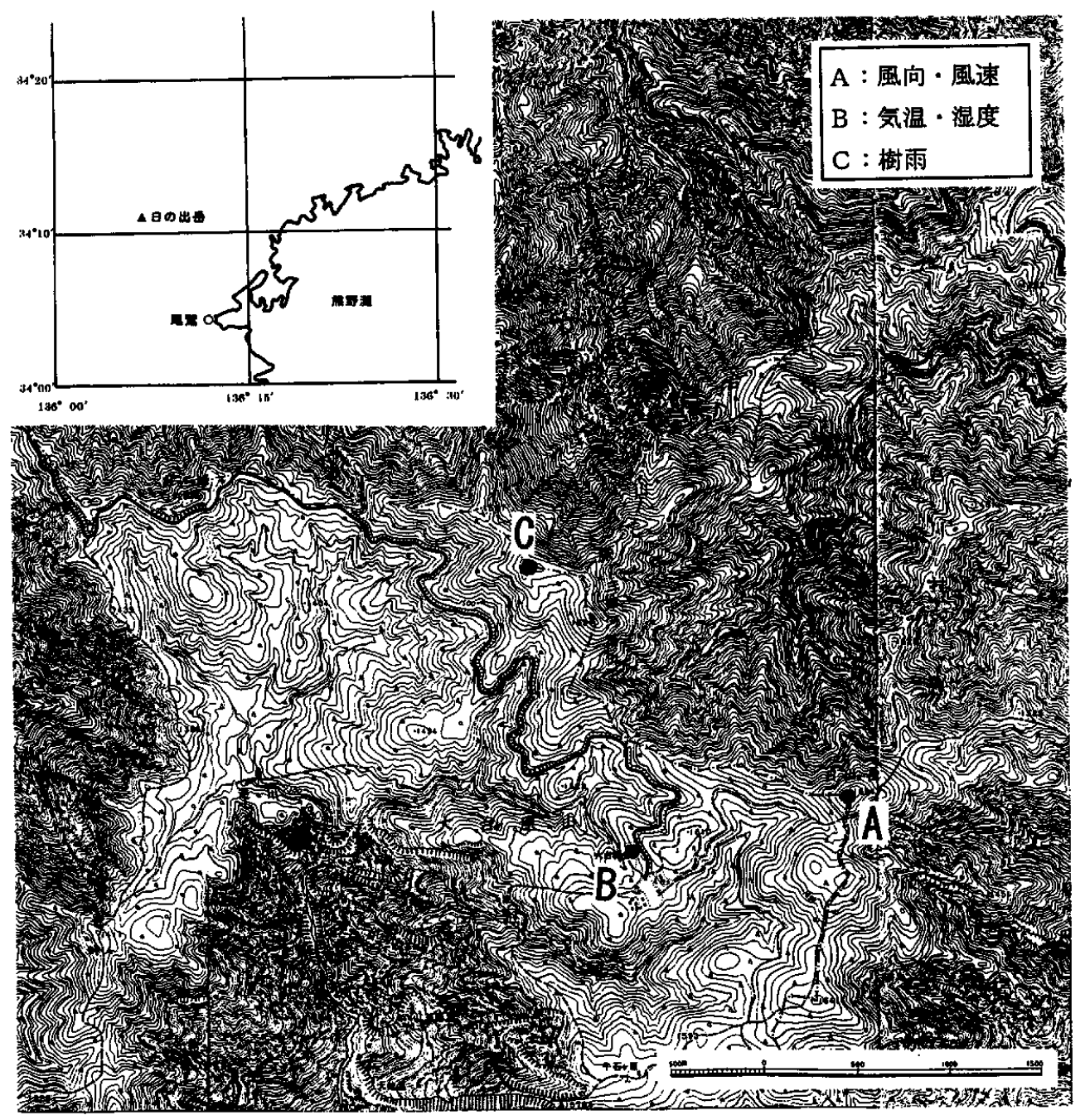

\section{图一1 貺測地点の位囯}

これらの関係を模式的に，図一 5 に示した。

この方法で求めた樹雨量の, 観測期間中の合計は, 広葉樹が $94 \mathrm{~mm}$, 針葉樹が $90 \mathrm{~mm}$ であった。これらは, 林外雨量の約 $30 \%$ に相当する.これは，水管理の上 では，無視できない量と考えられる．欠測期間，観 測開始前の春期を考虑すれば, 年間では、100mmを超 す樹雨量があるものと思われる。

\section{IV. 樹雨発生時の気象条件}

樹雨が発生した降雨(表一2の 2 印の降雨)の気象 条件を, 通常の降雨( $\triangle$ 印のついていない降雨) と比較 して，調べた。まず， $\Delta$ 印の降雨事例での気象状況
を概観する。

№. $3: 6$ 月22日19時〜 6 月24日22時

22日から24日にかけても, 日本海南部に低気圧が 停滞していた，南海上に停滞する梅雨前線上を低気 圧が東進して近づき，23日の日中から夜にかけて近 畿地方の南海上を通過した。

低気圧が近づいてきた22日 7 時から, 風向が南東 になり，23日24時まで続いた。その後は北西の風に なった。低気圧が比較的遠くを通ったため, 風は 2 $\sim 5 \mathrm{~m} / \mathrm{s}$ 程度で弱かった。この間，22日13時頃から 24 日 9 時頃まで湿度 $100 \%$, 気温 $12 \sim 13{ }^{\circ} \mathrm{C}$ 状態が続 き，霧が発生していたと考えられる。 


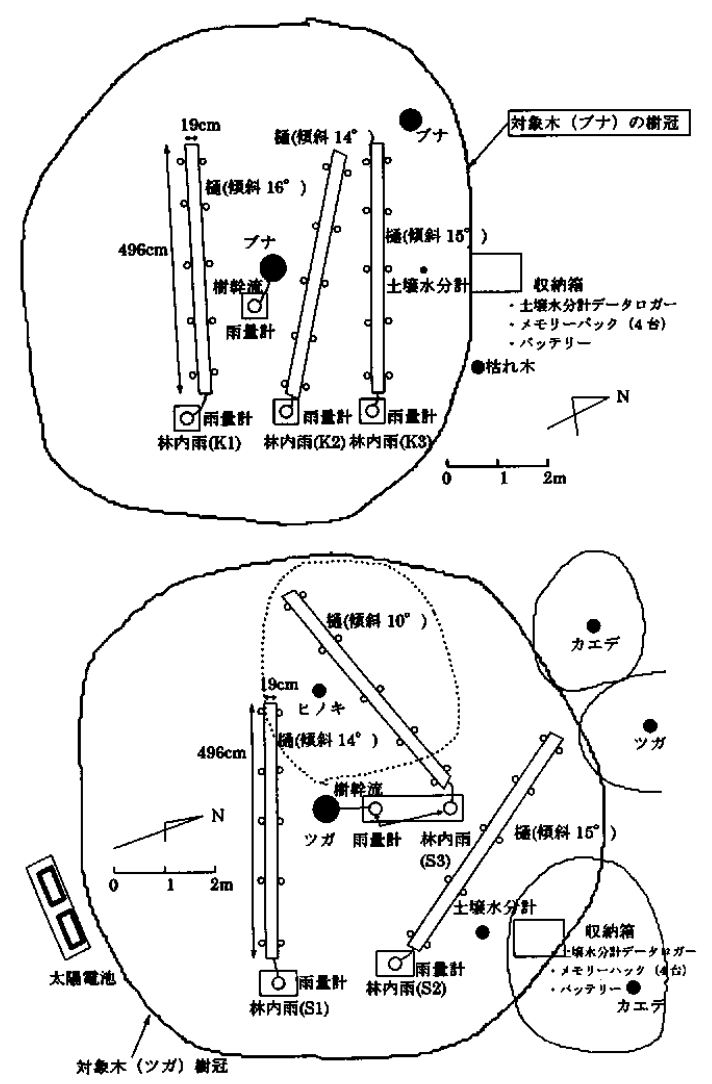

图一2 樹雨観測機器配置图

(上：広莱樹, 下：針葉樹)

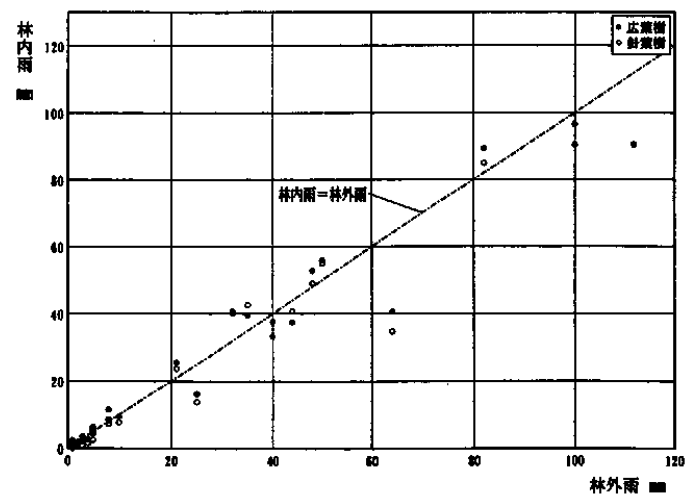

图一 3 林内雨量と林外雨量 (一雨雨量)
表一2 大台ヶ原における榯雨観測の集計衰 (積算雨量, 単位：m）

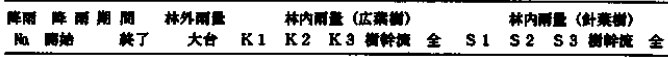

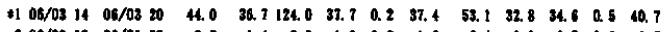

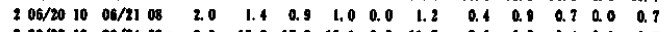

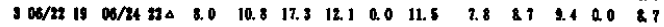

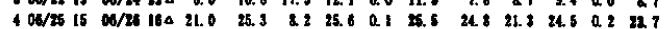

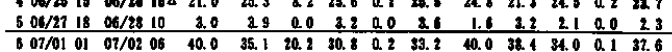

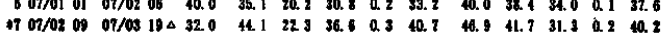

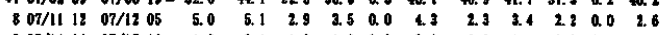

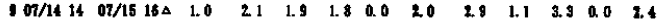

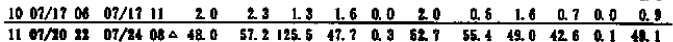

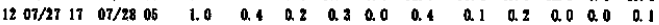

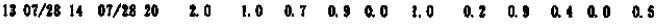

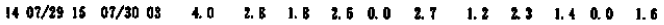

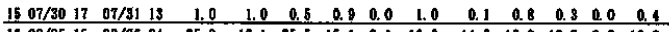

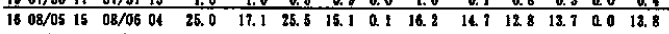

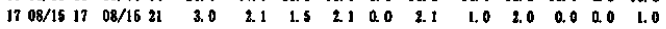

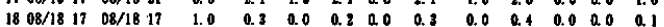

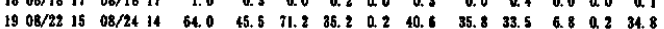

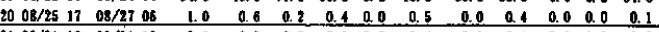

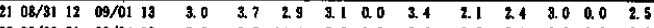

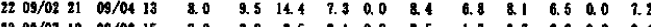

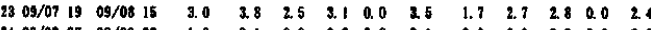

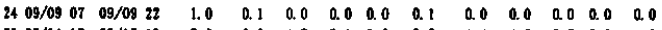

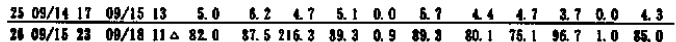

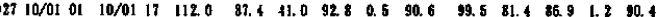

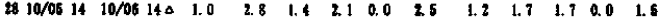

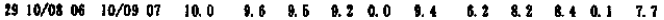

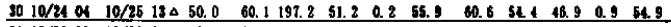

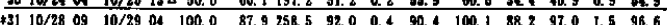

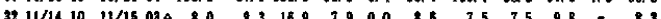

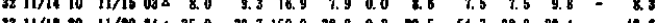

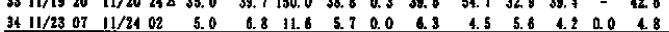

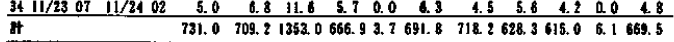

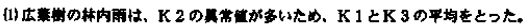

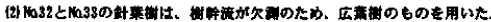

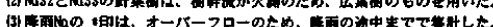

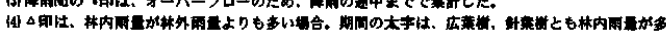
(1)

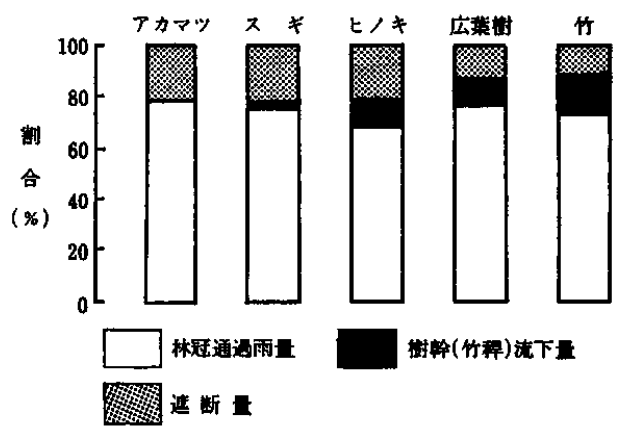

図一4 林内の雨量配分についての既往研究例

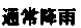

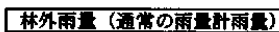

柇丙雪

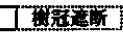

树两発生降雨

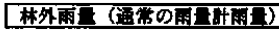

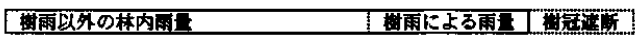

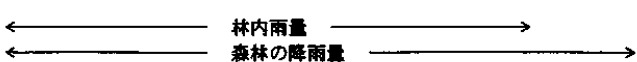

\section{図一 5 通常降雨と樹雨発生降雨の構成}



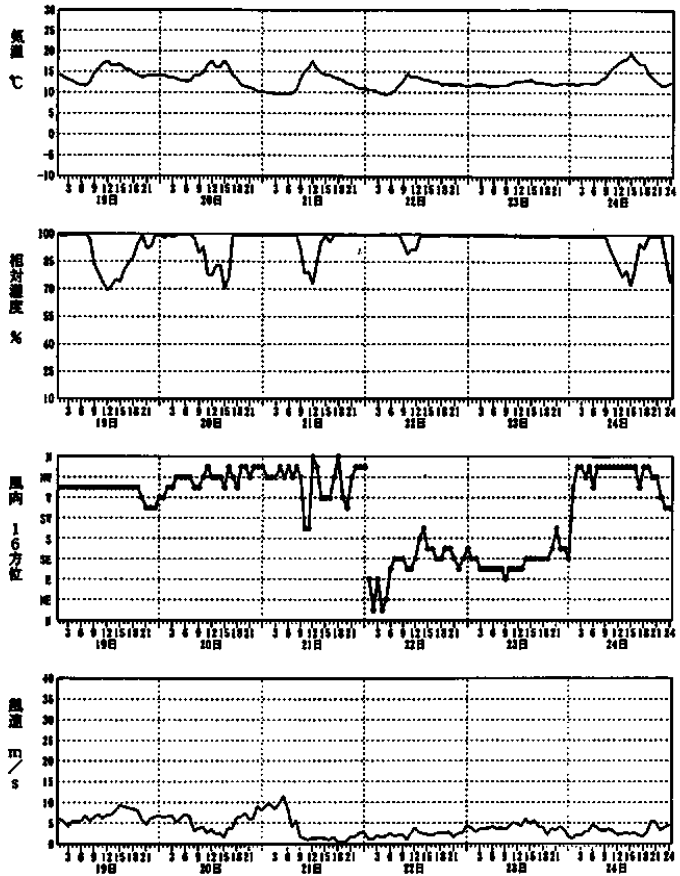

図一6 大台ケ原における気象要秦の覞測仕の経時 変化(1995年 6 月19日〜 6 月 24 日)

24日日中は気温が上がって湿度も下がったが, 夜 になると気温が下降したため，19時から22時にかけ て高湿度となり，放射性の霧が発生したと思われる。 図一6にこの間の気象要素の観測値の経時変化を一 例として示しておく。

№ $4 ： 6$ 月25日15時〜 6 月26日 16 時

梅雨前線上の九州西海上にあった低気圧が, 発達 しながら25日夜に近幾地方の南岸を通過した。これ とは別の低気圧が日本海を東進し，26日日中，北陸 地方にあった。

25日 7 時から南東の風となり, 南岸を低気圧が通 り過ぎた頃の26日 1 時からは、日本海の低気圧の影 響で, 西南西〜西北西の風となった. 風速は $5 \mathrm{~m} / \mathrm{s}<$ らいが持続した。この間，湿度は26日10時までほぼ $100 \%$ あり,霧が出ていたと思われる. その後, 気 温が上がって, 湿度は低下し, 霧は薄くなっていっ たと考えられる。

$\mathrm{Na} 7: 7$ 月 2 日09時〜 7 月 3 日19時

この期間は, 梅雨前線が近畿地方付近に停滞した。 前線は, 2 日朝加ら太平洋高気圧が強まって北上し たが，4 日には再び近畿南部まで南下した。
この間, 湿った南西〜西南西の風が支配的であり， 前線の南北振動に対応して, 風向は一時西北西〜北 西に変わった. 湿度はほほ $100 \%$ の状態が続き, 降水 や第の発生が考えられる。

№ $9 ： 7$ 月14日 14 時〜 7 月15日 16 時

梅雨前線が南下し，14日夜に近畿地方を弱まりな がら通過した。前線は15日には一時消姿した。

14日朝から15日11時頃まで, 北北西〜北西の風が $6 \sim 10 \mathrm{~m} / \mathrm{s}$ と比較的強く, 湿度はほほ $100 \%$ あった。 気温の変動も小さいことから, 霧が発生していたと 考えられる。

15日午後は風も弱まり, 高湿度ではあるが湿度が やや低下し，霧は薄くなったと思われる。

Na11：7月20日22時〜 7月24日08時

20日から22日にかけて梅雨前線が日本海南部に停 滞し, 太平洋高気圧の緑辺を趈る暖湿流の入りやす い気圧配置が続いた。 23日から24日は梅雨前線は消 姿したが，台風 3 号が日本海西部を北東進したため 暖湿流の入りやすい状態は継続した.

この期間は, 西南西〜南西の風が $3 \sim 10 \mathrm{~m} / \mathrm{s}<ら$ いであり，湿度はほぼ100\%であった。 22日21時に林 外雨が止んだ後も、24日朝まで霧が出ていたと思わ れる，23日日中は，湿度がやや下がり，霧が薄かっ たようである.

№26：9月15日23時〜 9 月18日11時

本州南岸に秋雨前線が停滞し, 南海上を台風12号 が北上した. 台風は17日朝に関東の南沖を通過し, 夜には三陸沖へ達した。

15日夜から 16 日朝は南東の風が $3 \sim 5 \mathrm{~m} / \mathrm{s}$ ，その 後, 東〜北東の風となり，14時以降は北〜北北西の 風となった，17日日中にかけて北北西の風が次第に 強まり, $20 \mathrm{~m} / \mathrm{s}$ 達した。この間, 17 日昼頃まではま とまった雨が降った。

18日 8 時頃までは湿度がほぼ $100 \%$, 寒気も入り， 降雨終了後も霧がかかっていたと考えられる.

№28：10月 5 日14時〜 10 月 6 日14時

5 日日中に日本海を気圧の谷が通過したあと, 寒 気が入ってきた．西のち北北西の風が次第に強まり， 5 日21時から 6 日12時は $7 \sim 12 \mathrm{~m} / \mathrm{s}$ に達した。 5 日 昼前から気温が低下し始め, 13 時には湿度が $100 \% に$ 達し，霧が発生したと考えられる。この状態は， 6 日昼頃まで続いた。

№.30：10月24日04時～10月25日 13 時

24日朝には，移動性高気圧が東の海上に去り，西 から低気圧や前線を含む気圧の谷が近づき，夜に大 
台ケ原を通過した. 24日は南東〜南西の風が次第に 強まり, 夜半頃には北西〜北北西の風に変わり, $10 \mathrm{~m} / \mathrm{s}$ 以上になった。湿度は，25日朝までほほ $100 \%$ て, 降雨が終了した25日 2 時 (大台観測所) 以降, しば らくは雺に覆われていたと考えられる。

№.32：11月14日10時〜11月15日03時

日本海を北東進する低気圧から延びる寒冷前線が， 14日夕方に大台ケ原を通過した，通過前は南西の風 が $7 \sim 10 \mathrm{~m} / \mathrm{s} く ら い$ 吹き, 湿度は $100 \%$, 気温も上昇 した. 通過後は, 気温が急激に下がり，15日には氷 点下になった。

14日15時から21時に弱い雨が降った(大台観測所)。 この前は, 暖かい湿った風の流入て，この後は，冷 たい空気の流入で籍が発生したと考えられる。しか し，夜には，蓩水となった可能性がある。

№.33：11月19日20時〜11月20日24時

19日夜に東シナ海に発生した低気圧が、20日朝に は紀伊半島沖に達し, 北東に進んだ。 20 日 9 時頃ま では, 南東のち南西の風が吹いて気温が上がったが, 昼前には北北西の風に変わって気温が下がり, 夜に は氷点下になった，20日20時から21日 8 時は, 風向 風速計が凍結していた可能性が大きい.この期間は, 湿度がほほ $100 \%$ でり，19日23時から20日10時は降 雨があった(大台観測所)が,降雨前は暖湿気の流入で, 降雨後は寒気の流入で霧が発生していたと思われる. 気温が氷点下になった 20 日夜は, 霧氷の可能性が大 きい.

なお，䇝が樹雨として滴下していることを傍証す る意味で，これら降雨事例での林内外雨の降雨期間 を表一 3 に示しておく，林内雨が林外雨より長く， 降雨によっては林外雨の 1 日ほど前から林内雨が記 録され，林外雨の 1 日以上あとまで続く例もある。 なお，これら降雨以外は，林外雨と同時刻に林内雨 の記録が始まり, 終了は林外雨の終了から数時間以 内となっている..もちろん, 雨量計の精度の問題も

\section{衰一 3 林外雨と林内雨の開始終了時刻(広葉樹)}

\begin{tabular}{|c|c|c|c|c|}
\hline 雨No. & 林外萧 & & 林内雨 & \\
\hline & 间始 & 称了 & 挏始 & 耛T \\
\hline 3 & $06 / 2302: 00$ & $06 / 23 \quad 11: 00$ & $06 / 22 \quad 19: 00$ & $06 / 2422: 00$ \\
\hline 4 & $06 / 25 \quad 16: 00$ & $06 / 2608$ & $06 / 25 \quad 15: 00$ & $06 / 26 \quad 16: 00$ \\
\hline 7 & $07 / 02 \quad 15: 00$ & 一 & 07/02 09:00 & - \\
\hline 9 & $07 / 1507: 00$ & $07 / 15 \quad 07: 00$ & $07 / 14 \quad 14: 00$ & $07 / 15 \quad 16: 00$ \\
\hline 11 & $07 / 21 \quad 23: 00$ & $07 / 22 \quad 21: 00$ & $07 / 20 \quad 22: 00$ & $07 / 24 \quad 08: 00$ \\
\hline 26 & $09 / 1604: 00$ & $09 / 17 \quad 13: 00$ & $09 / 15 \quad 23: 00$ & $09 / 18 \quad 11: 00$ \\
\hline 28 & $10 / 05 \quad 14: 00$ & $10 / 05 \quad 11: 00$ & $10 / 05 \quad 14: 00$ & $10 / 06 \quad 10: 00$ \\
\hline 30 & $10 / 2404: 00$ & $10 / 25 \quad 02: 00$ & $10 / 2404: 00$ & $10 / 25 \quad 13: 00$ \\
\hline 32 & $11 / 14 \quad 16: 00$ & $11 / 1421: 00$ & $11 / 1410: 00$ & $11 / 1503: 00$ \\
\hline & $11 / 20 \quad 01: 00$ & $11 / 2016: 00$ & $11 / 1920: 00$ & $11 / 2100: 0$ \\
\hline
\end{tabular}

あるが、これらは降雨の前後で雨量計に捕捉されな い霧が樹雨として滴下していることを意味していよ う.

次に樹雨発生降雨と通常降雨の風配図を出現時間 数でみると(図一7(a), (b)), 樹雨発生降雨では, 北北 西が最も多く，次いで西南西と南西である，通常降 雨で, 南西から北北西が多いのとは異なった分布を 示している.

樹雨発生降雨は, 気象要素の時系列図と併せて考 えると南西や西南西の風によって, 湿った暖かい空 気が流入して, 霧が発生し(通常の降雨もある), 北北 西の冷たい空気が入って，霧が冷やされ樹雨が発生 しやすくなると考えられる。

また, 風向別に, 最大風速, 平均風速, 最小風速 を, 樹雨発生降雨と通常降雨についてそれぞれ比較

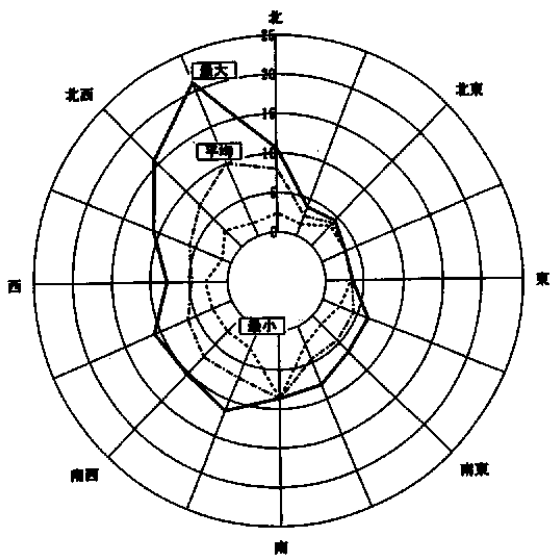

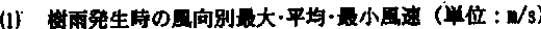

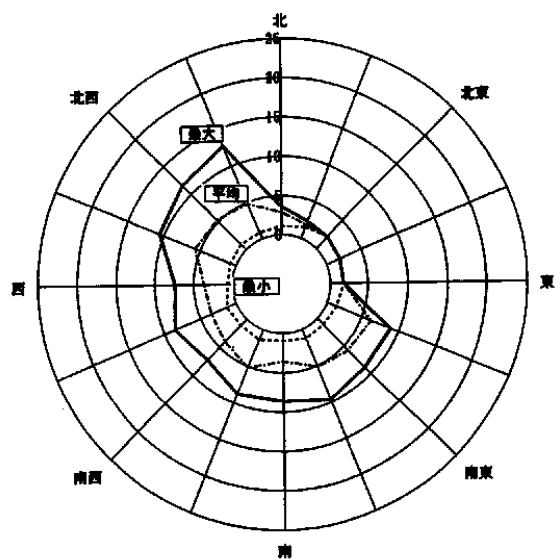

(2)

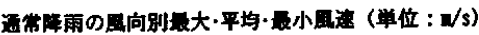

图-7 風向別出現頻度 (時間数) (1) 樹雨発生時, (2) 通常降雨 


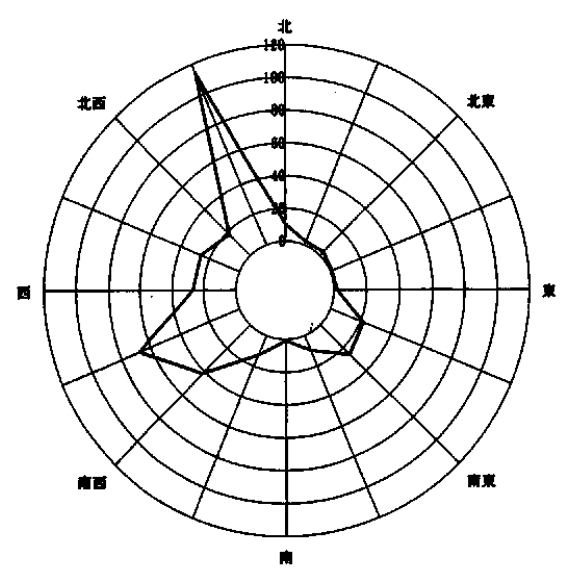

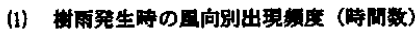

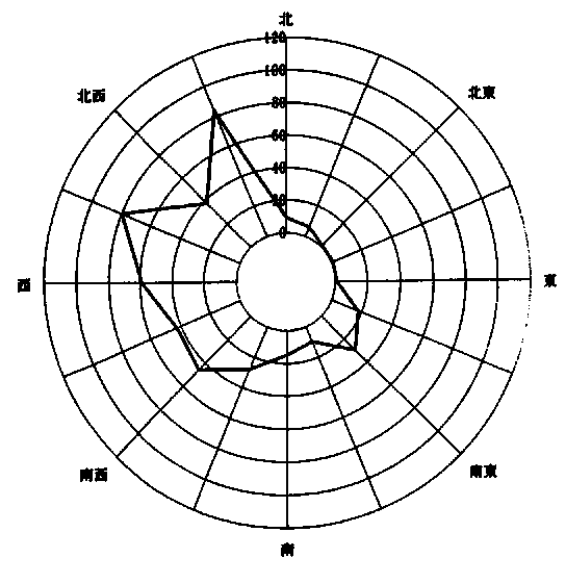

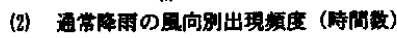

图一8 風向別最大・平均・最小風速 (単位 $: \mathrm{m} / \mathrm{s}$ ) (1) 樹雨発生時, (2) 通常降雨

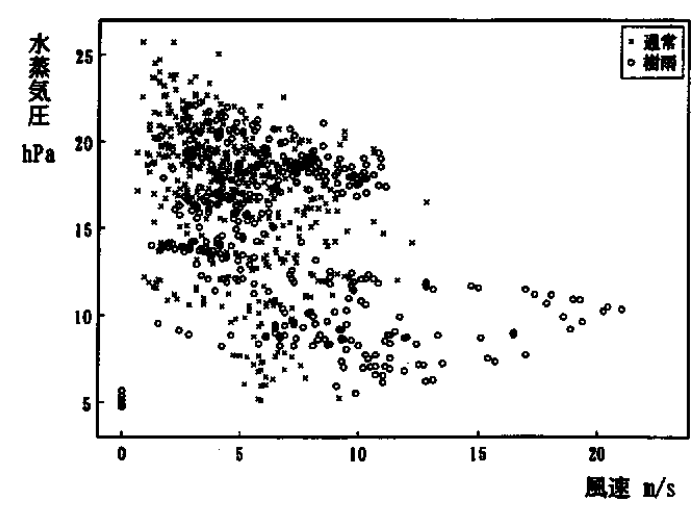

图一－梋雨発生と水蒸気圧・風速との做保
すると (図一8(a), (b)), 樹雨発生降雨では, 出現頻度 の多い北北西や南西, 西南西の風が, 通常降雨に比 べて，風速が大きいことがわかる，樹雨は，南西， 西南西からの暖湿気や, 北北西からの寒気の流入が 強いほど発生しやすいと考えられる。

加えて図一9に横軸に風速, 縌軸に水蒸気圧を とって, 毎時のデータをプロットした. 風速が $10 \mathrm{~m} / \mathrm{s}$ 程度以上であれば, 水蒸気圧が $5 \mathrm{hPa}$ 程度以上で, ほ とんどの場合樹雨が発生している. 風速が $10 \mathrm{~m} / \mathrm{s}$ 程 度より弱い場合は, 水蒸気圧が10〜20hPa程度で樹 雨が発生するが, 同じ条件で発生しない場合も多く なっている.

\section{V. 樹雨と土墥保水量の变化}

土境水分の観測は, 雨量計に降雨が観測されてい ない期間での, 樹雨による土壤水分の増加を検出す る目的で行ったが, 結果的にはこうした状況は観測 できなかった。 その理由として,

・樹雨の生じるような霧は, 降雨の前後に発生する ことが多く降雨自体による土壤水分の変化と区別 できなかった。

・ 区別できるとすれば, 降雨前の樹雨であるが, 今 回の観測では樹雨の強度は小さく土壤水分計が反 応するまでには至らなかった。

が考えられる。

ここでは, 樹雨地域の土壤保水量変化の例として 図一10にNN26の観湘結果を示す. 土㙵保水量は, 湘 定された各層の平均体積含水率から試算した。

降雨時には, 土㙵保水量が増加し, 降雨終了後は 徐々に減少している. 降雨量に対して保水量の増加 量(約 $200 \mathrm{~mm}$ )がやや大きいが, これはセンサー挿入地 点の局所的な影笠(岩石, 木の根, 土壤とセンサーの隙 間など)や斜面上部からの流入が考えられる.

一方, 無降雨時の保水量の最大は $500 \mathrm{~mm}$ 程度であり, 無降雨期間が長い場合に小さくなり, 最小は $420 \mathrm{~mm}$ らいであった.このことから, 大台ヶ原での表屬土 壤の保水量の変動幅は, 約 $80 \mathrm{~mm}$ である. 樹雨が発生 するような湿罣な条件であるため, 森林全体として は, かなりの保水量を維持している。 


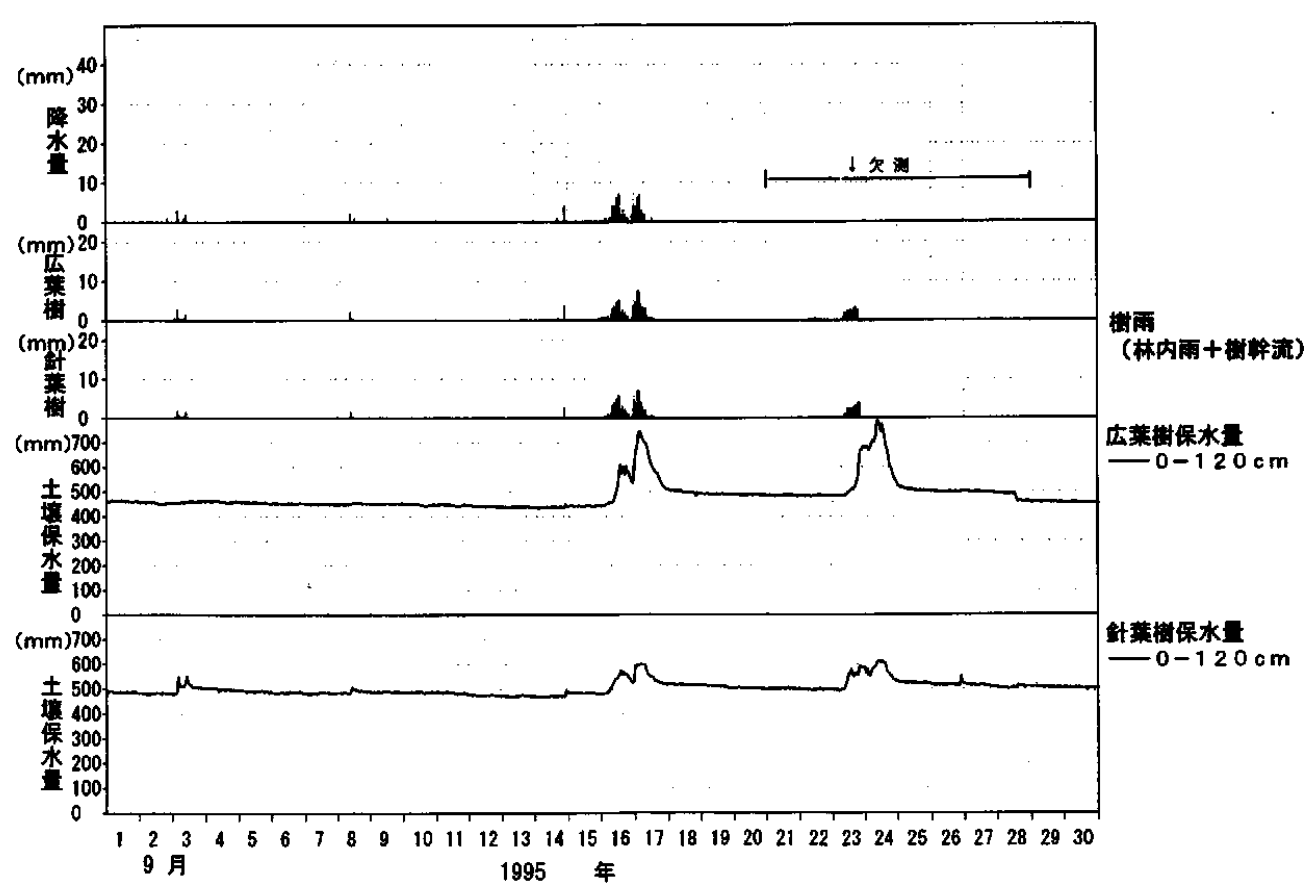

图一10 土壤水分より推定した土境保水量の時系列変化 (1995年 9 月)

\section{VI. おわりに}

樹雨の量を把握するために，建設省大台雨量観測 所付近の森林に, 環境庁の許可の下で，林内雨，樹 幹流，土壤水分の観測を実施した。

林内雨量と林外雨量とを比較し, 樹雨の量を計算 したところ，観測できた期間については，広葉樹が $94 \mathrm{~mm}$ ，針葉樹が $90 \mathrm{~mm}$ あった。これらは，林外雨量 の約 $30 \%$ に相当し，これは，水管理上，無視できな い量と考えられる. 欠測期間, 観測開始前の春期を 考慮すれば, 年間では, $100 \mathrm{~mm}$ 超す樹雨量があるも のと推察される.

今後とも観測地点の観測精度を高め, 観測を継続 し, 樹雨発生の気象条件を一層明らかにするととも に, 日本一多い雨が降る大台ケ原の降雨メカニズム
に樹雨発生がどのように関わるのかどうか, 詳細な 微物理過程を導入した降雨シミュレーションモデル の展開などを通して考察していきたい.

\section{参考文献}

真山俊雄 (1923)：大台ケ原山上の樹雨に就いて, 森 林治水気象彙報 1 号(2), pp.9-19.

鈴木清太郎(1959)：森林と水源涵養, 天気Vol. 6, No11, pp.353-360.

開発一郎 (1992)：不飽和水分量測定におけるTEM 波TDR法の有効性, 京都大学防災研究所水資源研 究センター報告, $41, \mathrm{pp} .90-94$.

服部重昭・阿部敏夫(1989)：竹林における降雨遮断 特性, 水利科学 $\mathrm{No}$. 186, pp. 36-53.

(1996年 6 月 6 日受付, 1996年 8 月17日受理) 
大台ヶ原における樹雨観測

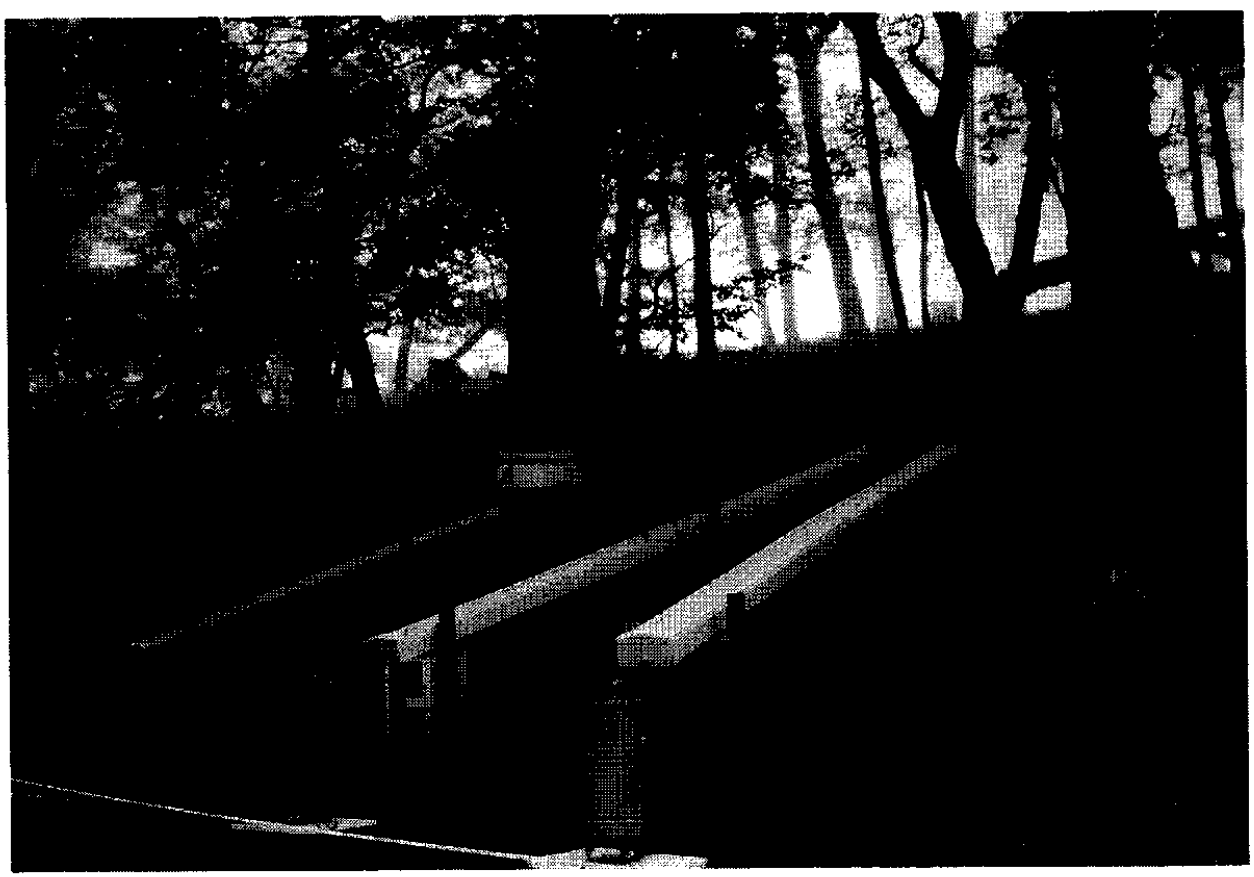

針葉樹林におりる樹雨観測

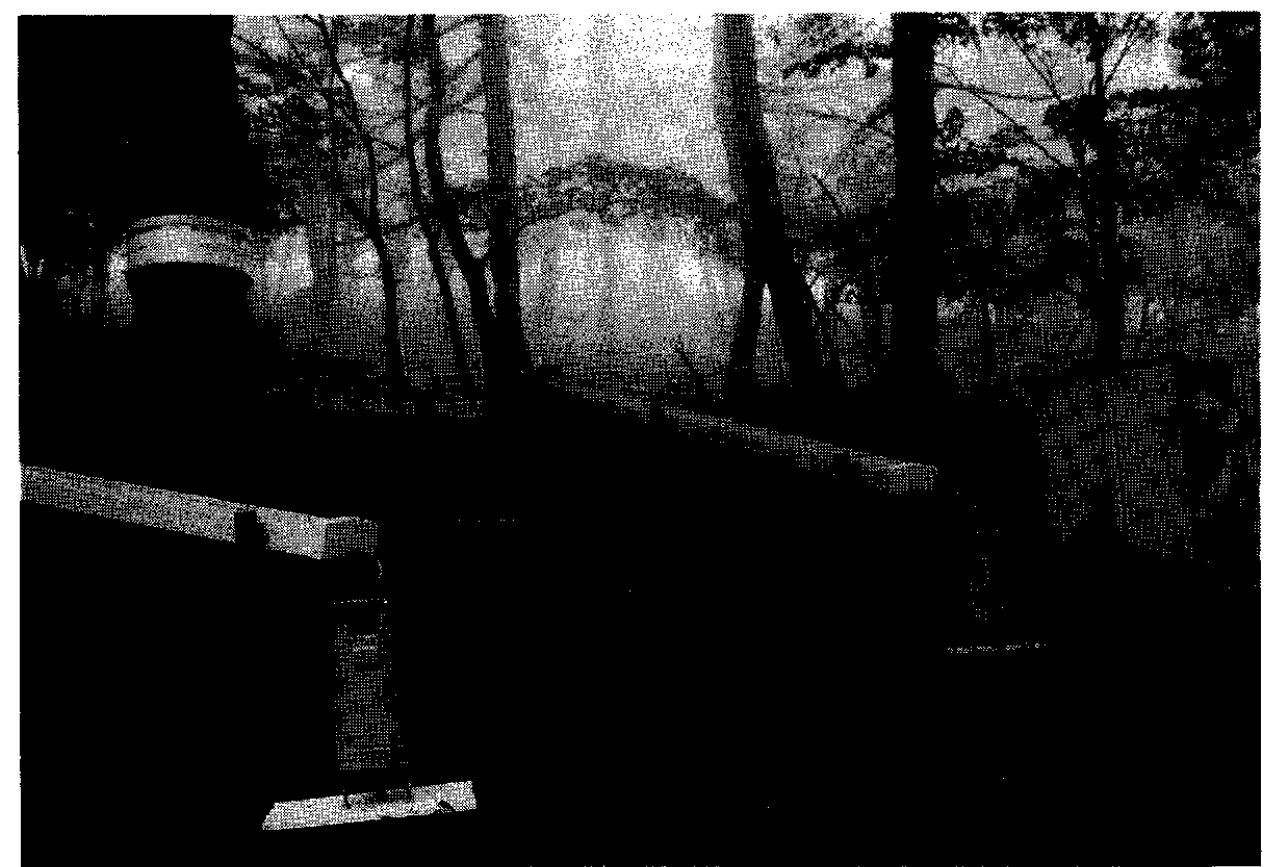

広葉樹林における樹雨観測

杼( 3 本)に落ちる降雨と樹幹流をそれぞれ転倒ます雨量計に集め、 小屋の中に収めたデータロガーに自劫妃録する。 （本誌534〜 541ページに閔尰鍮文揭部） 